\title{
Use of the Polynomial Separation and the Gravity Spectral Analysis to Estimate the Depth of the Northern Logone Birni Sedimentary Basin (CAMEROON)
}

\section{Jean Jacques Nguimbous-Kouoh ${ }^{1}$, Simon Ngos III' ${ }^{1}$, Theophile Ndougsa Mbarga ${ }^{2}$, Eliezer Manguelle-Dicoum ${ }^{3}$}

\author{
${ }^{1}$ Department of gas and petroleum exploration, Institute of Mines and Petroleum Industries, University of Maroua, Maroua, Ca- \\ meroon \\ ${ }^{2}$ Department of Physics, Advanced Teacher's Training College, University of Yaoundé 1, Yaoundé, Cameroon \\ ${ }^{3}$ Department of Physics, Faculty of Science, University of Yaoundé I, Yaoundé, Cameroon \\ Email: *nguimbouskouoh@yahoo.fr
}

How to cite this paper: Nguimbous-Kouoh, J.J., Ngos III, S., Mbarga, T.N. and Manguelle-Dicoum, E. (2017) Use of the Polynomial Separation and the Gravity Spectral Analysis to Estimate the Depth of the Northern Logone Birni Sedimentary Basin (CAMEROON). International Journal of Geosciences, 8, 1442-1456.

https://doi.org/10.4236/ijg.2017.812085

Received: September 28, 2017

Accepted: December 26, 2017

Published: December 29, 2017

Copyright $\odot 2017$ by authors and Scientific Research Publishing Inc. This work is licensed under the Creative Commons Attribution International License (CC BY 4.0).

http://creativecommons.org/licenses/by/4.0/

\section{(c) (i) Open Access}

\begin{abstract}
Many scientists used the power spectrum of the gravity anomaly to obtain the average depth of the disturbing surface or equivalently the average depth to the top of the disturbing body. The spectrum of gravity anomaly due to layered source is separated into multiple segments in frequency domain that can be interpreted in terms of mean depth of the interface. The half of the slope of the segments gives the mean depth of the interfaces. This study aims to estimate the average residual depth anomalies of various regions of the northern Logone Birni sedimentary basin of Cameroon using polynomial separation of gravity anomalies, and spectral analysis along different profiles (segments). The profiles were derived from residual anomaly maps obtained by fitting the Bouguer anomalies, the interpretation used polynomial separation and depth average was done using spectral analysis. Positive and negative residual gravity anomalies were highlighted and their interpretation revealed the structural directions of the sedimentary basin (NW-SE and NE-SW), as well as an intimate relationship between the negative anomalies and the northern Logone Birni sedimentary basin. Three distinct residual anomalies were identified over the Goulfey, Tom Merifine and Tourba basin with an average depth varying between $0.24 \mathrm{~km}$ and $4.55 \mathrm{~km}$.
\end{abstract}

\section{Keywords}

Gravity Anomalies, Qualitative Interpretation, Spectral Analysis, Logone Birni 


\section{Introduction}

The Logone Birni sedimentary Basin is located in the far north region of Cameroon, south of Lake Chad (Figure 1(a)). It covers an area of approximately $27.000 \mathrm{~km}^{2}$ and it is part of the West and Central African Rift system (WCARS). The West and Central African Rift system is divided into two Cretaceous subsystems genetically linked, but physically separated [1], named the West African Rift Subsystem (WARS) and the Central African Rift Subsystem (CARS). [2] indicated that these two rift subsystems, although genetically related, present some structural differences. To study the structure and understand the tectonic setting of the Logone Birni Basin, geophysical analysis and interpretation based on seismic reflection data coupled with gravity, magnetic and remote sensing data were used. The structure basement conditions of basin infill and distribution of buried volcanic bodies' were elucidated. The results confirmed the basic knowledge of the ancient tectonic and geophysical models of WCARS [2] [3].

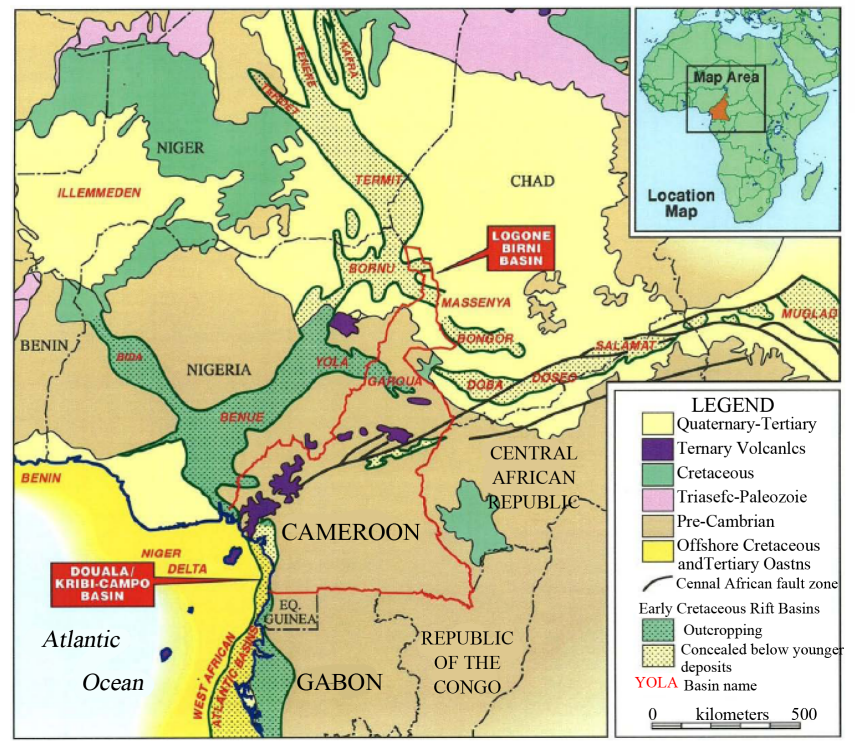

(a)

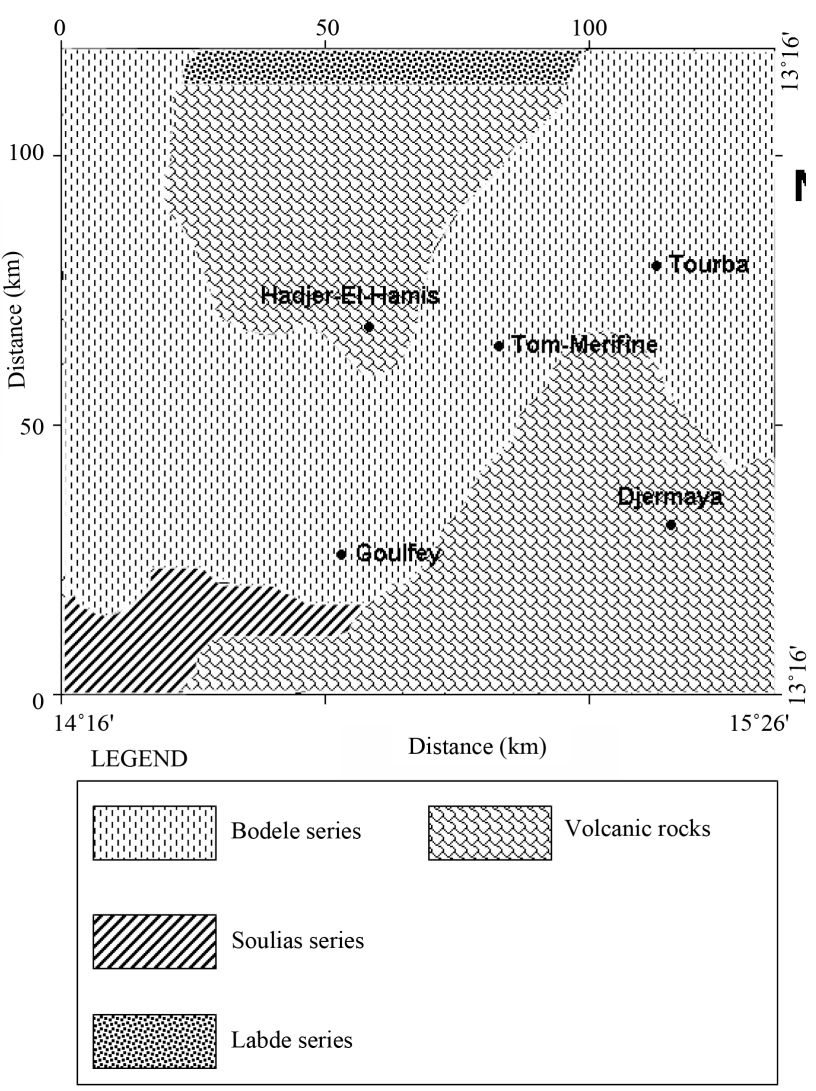

(b)

Figure 1. (a) Simplified geological map of Cameroon and adjacent areas (modified from [2]). The map shows distribution of different sedimentary basins: localization of the Logone Birni Basin in far north of Cameroon; (b) Simplified geological map of the study area (modified from [5]). 
Significant hydrocarbon deposits were discovered in the sedimentary basins which are part of the WARS and CARS (e.g., the Doba basin in Chad, Muglad and Melut basins in Sudan). Despite the scientific and economic importance of these zones, recent surveys date from the 1960s to the 1990s [1] [4], and most of the data are owned by oil companies, and not always available to universities.

In this study, we calculated the average depths of the basin using spectral analysis of the residual anomaly maps obtained after filtering the Bouguer anomaly map computed by [4] [5] the northern Logone Birni Basin (Figure 1(a)).

\section{Regional Geology}

The study area (Figure 1(a), Figure 1(b)) is located in the transition zone between the Central and the West African Rift System (WCARS) [6] [7]. This area was affected by the Pan-African orogeny (750 - 550 million years) which generated the main part of lineaments and faults in the Palaeozoic (550 - 130 million years), the Cretaceous (130 - 75 million years), the Maastrichtian-Palaeogene (75 - 30 million years) and the Neogene-Recent (30 - 0 million years).

The region is under a tropical climate, which favours the growth of a shrubby savannah and sparse forest vegetation. The Lake Chad region has the lowest altitude $(280 \mathrm{~m})$. The main rivers that drain the region are the Chari and the Logone; the Chari is tributary to the Lake Chad while the Logone is an effluent of the Chari. The geological history of the region is related to the formation of the Chad basin.

Throughout the Lower Cretaceous, the Chad basin was an extension zone between the western and central Africa plates. It was subject to various tectonic activities from the primary era to the Quaternary era marked by relief inversions [8] [9]. The present sedimentary cover which has an average depth of $600 \mathrm{~m}$ or more is the result of an interaction between two main factors: the Lake Chad transgression in the humid period and the lacustrine transgressions during the more arid periods marked by Aeolian erosion that strongly removes deposited materials [10] [11] [12]. The lacustrine transgressions can be delimitated over three main geological periods. This delimitation was made possible thanks to the discovery of sedimentary basins that correspond to palaeo-shorelines of the lake [13] [14] [15] [16]:

- The first transgression might have started at the end of the Tertiary, resulting to basin infill in the Middle Quaternary from material derived from partial ablation of ancient deposits and border massifs. The process was amplified by subsidence of the basin and, inversely, by massifs uplifting.

- The second transgression dates from about 21.000 years.

- The third transgression linked to the third humid period, dated from 12.000 years ago and marks the constitution of the first trace of the actual drainage pattern.

The northern Logone Birni Basin is a sedimentary plain covered by sandy clayey alluvial deposits of quaternary age. Its lowest altitude makes it vulnerable to regular flooding by the River Chari and the Lake Chad. The sedimentary cov- 
er date from the Tertiary to the Quaternary throughout the region. This cover is made by river alluvia, lacustrine, wind sediments, and shows three main series [10] [14] (Figure 1(b)):

- The Bodele series constituted by lightly differentiated sediments of the Upper Tertiary composed of sand and sandstone with some clayey intercalations. This series which date from the Pliocene is mainly fluvial.

- The Soulias series (Middle and upper Pleistocene) constituted by Aeolian sand and lacustrine limestone.

- The Labde series, which includes thin lacustrine deposits date from 2400 years to recent.

The sequence is underlained by granitic, gneissic and migmatitic basement rocks which appear at variable depths.

\section{Methods}

\subsection{The Polynomial Separation Method}

The polynomial separation method was used to produce the first, second and third degree residual maps. The algorithm by [17] [18] was used to adjust the polynomial surfaces to the Bouguer anomaly map [5] [19] [20]. This method is based on the analytical least square method and the polynomial decomposition series.

The least-square method was used to compute the mathematical surface which gave the best fits to the gravity field within specific limits [5] [19] [20]. This surface is considered to be the regional gravity anomaly. The residual was obtained by subtracting the regional field from the observed gravity field. In practice, the regional surface is considered as a two-dimensional polynomial. The order of this polynomial depends on the complexity of the geology in the study area. The first, second and third-order polynomial surfaces of the regional anomaly obtained in this work is not presented, but the corresponding residual anomaly is presented in Figure 3.

\section{Mathematic Formulation of the Method}

The Bouguer anomaly $B(x, y)$ in the given point $M(x, y)$ of the earth in cartesiane coordinates is governed by the relation:

$$
B\left(x_{i}, y_{i}\right)=A\left(x_{i}, y_{i}\right)+R\left(x_{i}, y_{i}\right)
$$

$B\left(x_{i}, y_{i}\right)$ is the sum of the residual anomaly $A\left(x_{i}, y_{i}\right)$ and the regional anomaly $R\left(x_{i}, y_{i}\right)$.

The surface $F\left(x_{i}, y_{i}\right)$ which is adapted to the gravity field data $g(x, y)$ is given by the following relation (Radhakrishhna and Krishnamacharyulu, 1990):

$$
\begin{aligned}
F\left(x_{i}, y_{i}\right)= & C_{1}+C_{2} X_{i}+C_{3} Y_{i}+C_{4} X_{i}^{2}+C_{5} X_{i} Y_{i}+C_{6} Y_{i}^{2}+\cdots \\
& +C_{M-N} Y_{i} X_{i}^{N-1}+C_{M-N-1} Y_{i} X_{i}^{N-1}+\cdots+C_{M} Y_{i}^{N}
\end{aligned}
$$

where $N$ is the order of the polynomial, $M=\frac{(N+1)(N+2)}{2}$ the number of terms of the polynomial, and $C_{M}$ the coefficients to be determined: 
The first order Polynomial is:

$$
F\left(x_{i}, y_{i}\right)=C_{1}+C_{2} X_{i}+C_{3} Y_{i}
$$

The second order polynomial is:

$$
F\left(x_{i}, y_{i}\right)=C_{1}+C_{2} X_{i}+C_{3} Y_{i}+C_{4} X_{i}^{2}+C_{5} X_{i} Y_{i}+C_{6} Y_{i}^{2}
$$

The third order polynomial is:

$$
\begin{aligned}
F\left(x_{i}, y_{i}\right)= & C_{1}+C_{2} X_{i}+C_{3} Y_{i}+C_{4} X_{i}^{2}+C_{5} X_{i} Y_{i}+C_{6} Y_{i}^{2} \\
& +C_{7} X_{i}^{3}+C_{8} Y_{i} X_{i}^{2}+C_{9} X_{i} Y_{i}^{2}+C_{10} Y_{i}^{3}
\end{aligned}
$$

We denote by $\varepsilon_{i}=B\left(x_{i}, y_{i}\right)-F\left(x_{i}, y_{i}\right)$ the difference between the homologous points of the experimental and analytical surfaces respectively and by $N_{0}$ the number of stations $P_{i}$ in which the Bouguer anomaly is known. The adjustment of the surfaces which consists in making the quadratic deviation minimal is expressed by:

$$
\begin{gathered}
E=\sum_{i=l}^{N_{0}} \varepsilon_{i}^{2} \text { then } \frac{\partial E}{\partial C_{k}}=0 \text { with } 1 \leq k \leq \frac{(N+1)(N+2)}{2} \\
E=\sum_{i=l}^{N_{0}}\left[B\left(x_{i}, y_{i}\right)-F\left(x_{i}, y_{i}\right)\right]^{2} \text { and } \frac{\partial E}{\partial C_{k}}=0
\end{gathered}
$$

We then obtain a system of (M) equations with (M) unknowns. The unknowns are the coefficients $C_{k}$ of the polynomial $F\left(x_{i}, y_{i}\right)$ of order $N$. Once the coefficients are determined we determine the analytic regional anomaly $R\left(x_{i}, y_{i}\right)=F\left(x_{i}, y_{i}\right)$ and the residual by:

$$
A\left(x_{i}, y_{i}\right)=B\left(x_{i}, y_{i}\right)-F\left(x_{i}, y_{i}\right)
$$

The polynomial method is particularly used when the amplitude of the residual anomalies is negligible compared to the regional one. Apart from the polynomial method there are other methods such as the upward continuation method.

\subsection{The Spectral Analysis Method}

The spectral analysis method was used to investigate the wave numbers of gravity residual anomalies and to estimate the depths of the bottom and top of the residual anomalies source bodies.

Many scientists used the calculation of the power spectrum from the Fourier coefficients to obtain the average depth of the disturbing surface or equivalently the average depth to the top of the disturbing body [21] [22] [23]. In order to estimate the depths of the bodies responsible for the observed gravity anomalies on the residual maps (Figure 3), it is necessary to define the power spectrum of a gravity anomaly in relation to the average depths of the disturbing interface. It is also important to note that the final equations are dependent on the definition of the wave numbers during Fourier transform. The fast Fourier transform (FFT) has been applied to an anomaly profile with $\mathrm{n}$ data. 


\section{Mathematic Formulation of the Method}

The approach is based on the following procedure that allows the determination of different depths [5] [24]. For the observed residual anomalies:

$$
f\left(x_{j}, z\right)=\sum_{j=0}^{n-1} A_{k} \mathrm{e}^{i 2 \pi x_{j}} \mathrm{e}^{ \pm 2 \pi k z}
$$

In this function the wavenumber $k$ is defined as $k=1 / \lambda$ and $A_{k}$ is the amplitude coefficients of the spectrum is defined as,

$$
A_{k}=\sum_{j=0}^{n-1} f\left(x_{j}, z\right) \mathrm{e}^{-i 2 \pi k x_{j}} \mathrm{e}^{ \pm 2 \pi k z}
$$

For an altitude of $z=0$, the amplitude coefficients of the spectrum can be written as,

$$
\left(A_{k}\right)_{0}=\sum_{j=0}^{n-1} f\left(x_{j}, 0\right) \mathrm{e}^{-i 2 \pi k x_{j}}
$$

Then the amplitude coefficients of the spectrum can be rewritten in terms of (3) as,

$$
A_{k}=\left(A_{k}\right)_{0} \mathrm{e}^{ \pm 2 \pi k z}
$$

The power spectrum $P_{k}$ is defined as,

$$
P_{k}=\left(A_{k}\right)^{2}=\left(P_{k}\right)_{0} \mathrm{e}^{ \pm 4 \pi k z}
$$

Taking the logarithm of both sides,

$$
\log _{\mathrm{e}} P_{k}=\log _{\mathrm{e}}\left(P_{k}\right)_{0} \pm 4 \pi k z
$$

We can plot the wavenumber, $k$, against $\log _{\mathrm{e}} P_{k}$ to attain the average depth to the disturbing interface. The interpretation of this plot requires an estimate of the best line fit of the lowest wavenumbers where a change in gradient is observed. The average depth can be estimated from Equation (6) as,

$$
\bar{H}=\frac{\Delta P}{4 \pi \Delta k}
$$

where $\bar{H}$ is the average depth, $\Delta P$ and $\Delta k$ are derivative of $P$ and $k$ respectively. The observed residual anomalies depths using power spectral approach as shown in Figures 4-6.

\section{Results and Discussion}

\subsection{Interpretation of Bouguer Anomaly Maps}

A map of the Bouguer anomalies represented with dotted lines is shown in Figure 2(a). This map contains about 700 measurement points in a zone limited between latitudes $12^{\circ} 11^{\prime}$ and $13^{\circ} 16^{\prime}$ North, and longitudes $14^{\circ} 16^{\prime}$ and $15^{\circ} 26^{\prime}$ East and covers an area of approximately $16,200 \mathrm{~km}^{2}$. This map with a $5 \mathrm{~km}$ grid size was obtained by kriging, with a variogram model that has an angle of 0 degree and an anisotropy coefficient of [4] [17]. The Bouguer anomaly map of the Northern Logone-Birni area (Figure 2(b)) is deduced from the map of Figure 2(a) 


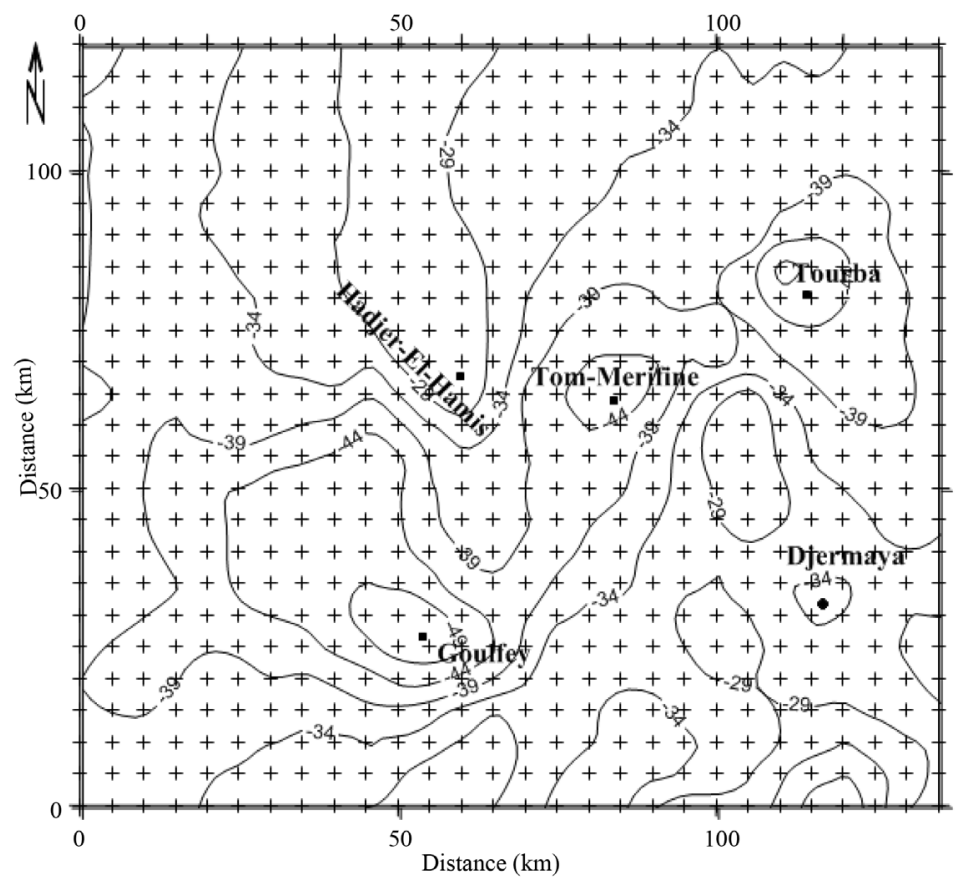

(a)

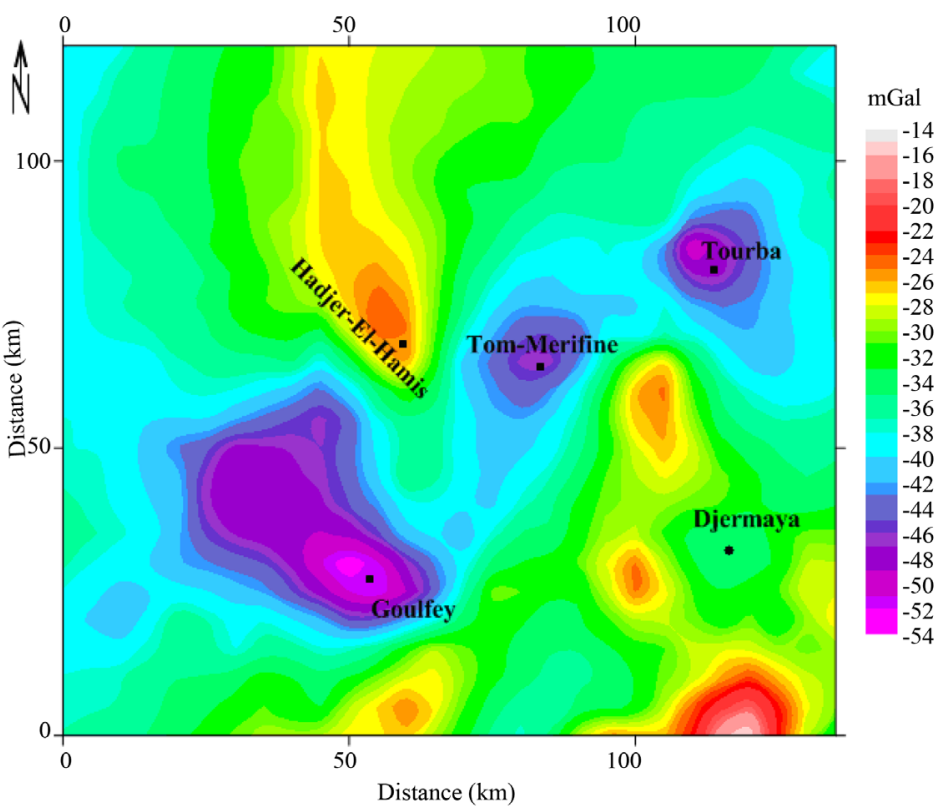

(b)

Figure 2. (a) Map of grid gravity stations distribution of Bouguer anomalies from [5] modified; (b) Bouguer anomaly map of the region from [5] modified.

with data uniformly sampled. This Bouguer gravity map is shown in Figure 2(b) with contour interval of $5 \mathrm{mGal}$. The observed data were separated into regional and residual anomalies before interpretation.

\subsection{Interpretation of Residual Anomaly Maps}

Qualitative interpretation is based on the geophysical information that can be 
extracted from the residual anomaly maps and their relationship with the geology of the region. The main features of the residual anomaly map (Figure 3 ) are very similar to those of the Bouguer anomaly map (Figure 2(b)).

The Bouguer anomaly map (Figure 2(b)) represents the resulting effects of the near surface and deep geological units within the survey area. This Bouguer anomaly map is characterized by the relative strong negative anomalies around Goulfey ( $-49 \mathrm{mGal})$, Tom Merifine ( $-44 \mathrm{mGal}$ ) and Tourba ( $-44 \mathrm{mGal})$. Those anomalies correspond to the northern Logone Birni basin infilled with sediments ([5] [10] [13] [15]). This map is also characterized by relative anomalies highs at Hadjer El Hamis and Djermaya which are in agreement with the uplifting of the basement as a result of magmatic intrusion in the corner of the basin by denser rocks such as rhyolites [5] [12] [15] [24] [25].

The residual anomaly map (Figure 3 ) obtained after polynomial separation portrays positive and negative values which may indicate an intrusion of the basement into sediments, and the northern Logone Birni sub-basin respectively. The residual anomalies found in the area are almost elliptical in shape and trend N-S, NW-SE, NE-SW; they are accompanied by a steep dipping gradient, which can be associated with structural geological boundaries.

The results of the structural trends of different anomalies are NW-SE and NE-SW. Tables 1-3, are in agreement with the results of [2] [3] and [7] which show that structural style in the Logone Birni Basin are mainly NE-SW. These styles correspond to tilted fault blocks associated with NNE-SSW senestral extension movements. While the NW-SE directions correspond to the directions WNW-ESE with normal faults and fault blocks associated with ENE-WSW dextral transtensional movements.

The structural directions observed here are similar to those of several major oil fields established in Sudan, for example, Muglad and Melut basins [25] [26].

\subsection{Interpretation of Spectral Analysis Profiles (Segments)}

The spectral analysis curves from profiles P1, P2 and P3 of Figures 4-6 shows the variation of the logarithms of the power spectrum with respect to the wavenumbers, and the slopes $(\mathrm{H})$ selected to estimate the depths. The shape of the power spectrum depends mainly on the values of the wavenumber along the profile. These values can be qualitatively estimated by the shape of the profile which depends on the geology of the area. The high wavenumbers $(0.3 ; 0.6)$ are related to the shallow anomalies, and the low frequencies $(0.0 ; 0.3)$ are related to the deepest anomalies ([2] [4]).

The profiles (P1, P2 and P3) have been selected along the large residual anomaly observed on the three residual maps, which correlate with the northern Logone Birni Basin (Figure 3). P1 is approximately orientated NW-SE and crosses the town of Goulfey. P2 and P3 are orientated NW-SE and cut-across the towns of Tom Merifine and Tourba.

Table 1 and Figure 4 show along profiles P1, the deepest anomalies with a 


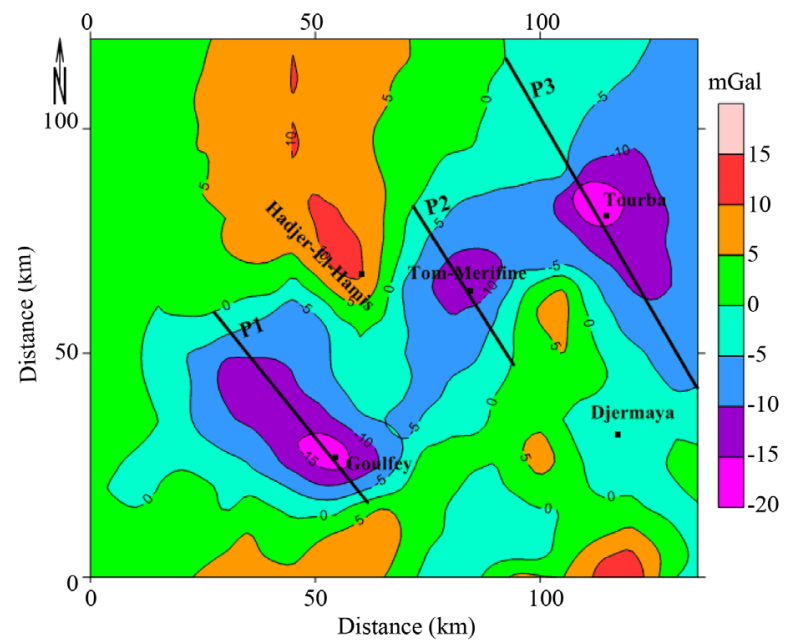

(a)

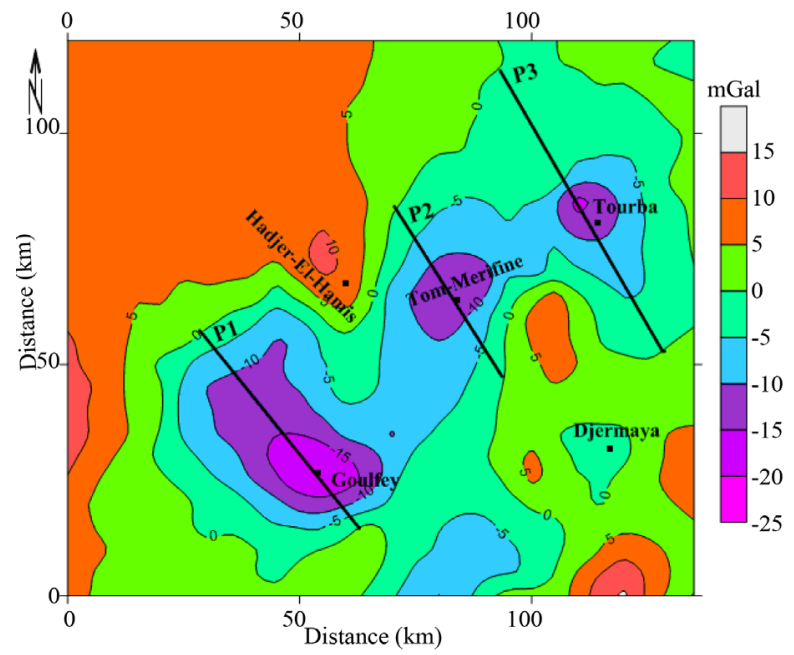

(b)

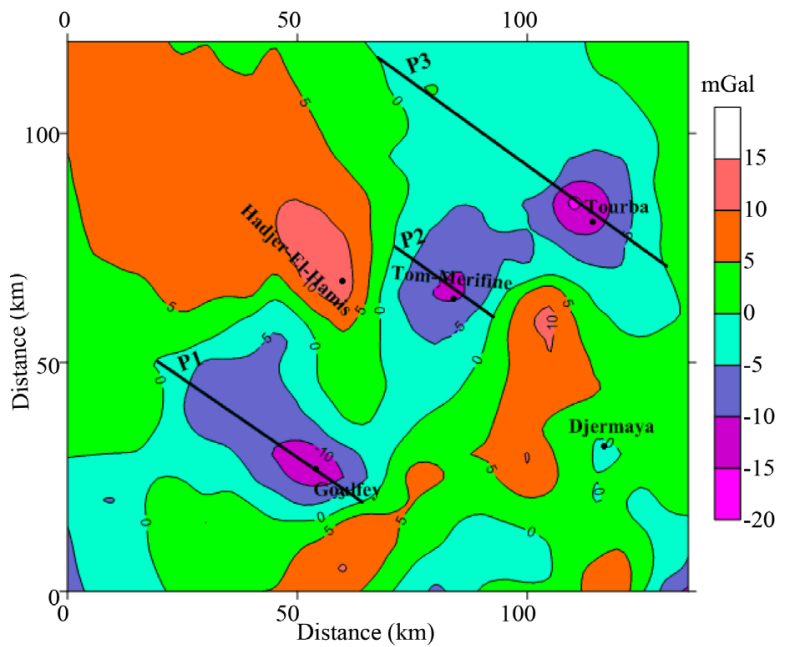

(c)

Figure 3. Residual maps of the study area showing gravity signature of the northern Logone Birni basin and profiles P1, P2 and P3: (a) The first order residual anomaly map of the region showing the profiles; (b) The second order residual anomaly map of the region showing the profiles; (c) The third order residual anomaly map of the region showing the profiles. 


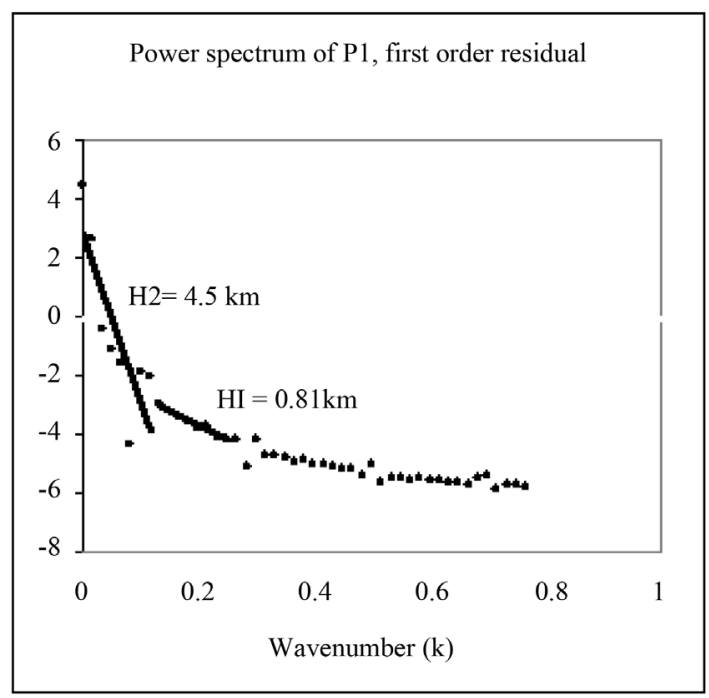

(a)

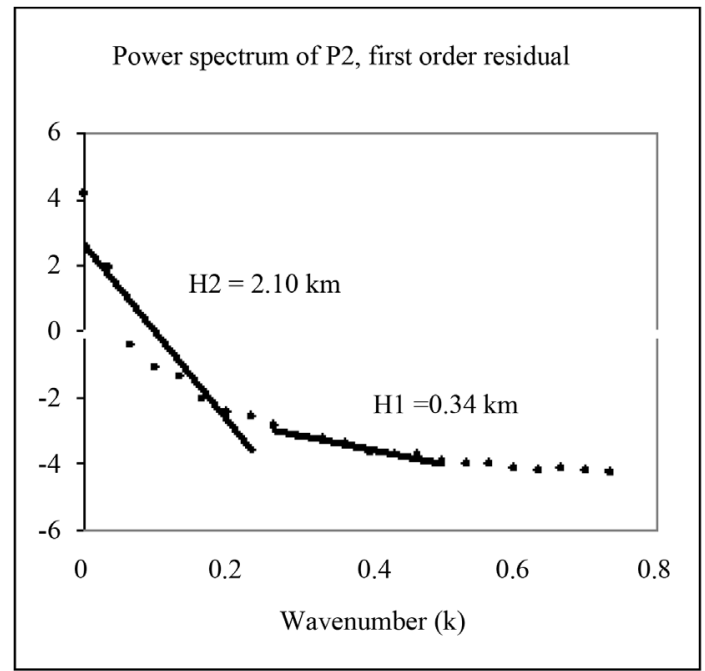

(b)

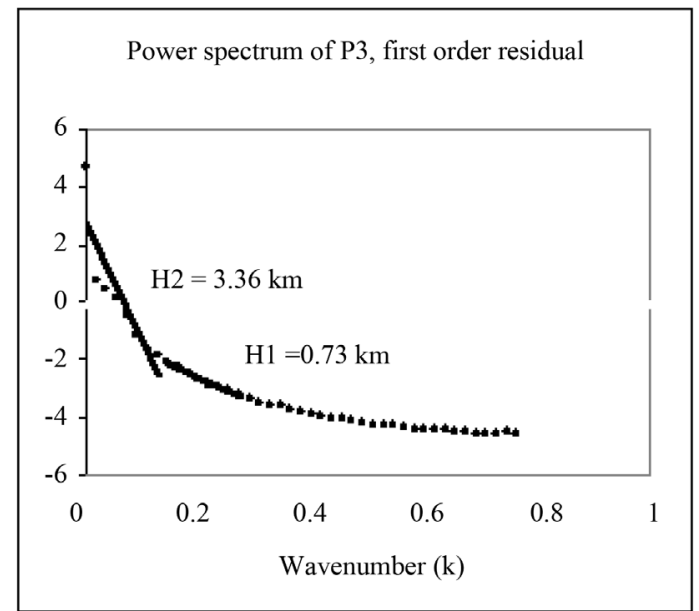

(c)

Figure 4. Power spectrum of profiles P1, P2 and P3 associated to the first degree trend gravity map. 
Table 1. Depths obtained by spectral analysis and characteristics of residual maps and profiles, for first degree polynomial fitting.

\begin{tabular}{ccccc}
\hline Profile & $\begin{array}{c}\text { Profile } \\
\text { direction }\end{array}$ & Anomaly direction & $\begin{array}{c}\text { Depths of shallow } \\
\text { sources H1 }(\mathrm{km})\end{array}$ & $\begin{array}{c}\text { Depths of deep } \\
\text { sources H2 }(\mathrm{km})\end{array}$ \\
\hline Profile 1 & NW-SE & NW-SE & 0.81 & 4.55 \\
Profile 2 & NW-SE & NE-SW & 0.34 & 2.10 \\
Profile 3 & NW-SE & NW-SE & 0.73 & 3.26 \\
\hline
\end{tabular}

Table 2. Depths obtained by spectral analysis and characteristics of residual maps and profiles, for second degree polynomial fitting.

\begin{tabular}{ccccc}
\hline Profile & Profile direction & Anomaly direction & $\begin{array}{c}\text { Depths of shallow } \\
\text { sources H1 }(\mathrm{km})\end{array}$ & $\begin{array}{c}\text { Depth of deep } \\
\text { sources H2 }(\mathrm{km})\end{array}$ \\
\hline Profile 1 & NW-SE & NW-SE & 0.47 & 4.00 \\
Profile 2 & NW-SE & NE-SW & 0.34 & 2.09 \\
Profile 3 & NW-SE & NW-SE & 0.49 & 2.96 \\
\hline
\end{tabular}

Table 3. Depths obtained by spectral analysis and characteristics of residual maps and profiles, for third degree polynomial fitting.

\begin{tabular}{ccccc}
\hline Profile & Profile direction & Anomaly direction & $\begin{array}{c}\text { Depths of shallow } \\
\text { sources H1 }(\mathrm{km})\end{array}$ & $\begin{array}{c}\text { Depth of deep } \\
\text { sources H2 (km) }\end{array}$ \\
\hline Profile 1 & NW-SE & NW-SE & 0.25 & 1.63 \\
Profile 2 & NW-SE & NE-SW & 0.24 & 1.67 \\
Profile 3 & NW-SE & NW-SE & 0.49 & 3.84 \\
\hline
\end{tabular}

depth of about $4.55,4.00$ and $1.63 \mathrm{~km}$, while the depth of the shallowest anomalies is at $0.81,0.47$, and $0.25 \mathrm{~km}$.

Table 2 and Figure 5 show along profiles P2, the deepest anomalies with a depth of about 2.10, 2.09 and $1.67 \mathrm{~km}$ and the shallowest anomalies with a depth of $0.34,0.34$ and $0.24 \mathrm{~km}$.

Table 3 and Figure 6 show along profiles P3, the deepest anomalies with a depth of about $3.26,2.96$ and $3.84 \mathrm{~km}$ and the shallowest anomalies with a depth of $0.73,0.49$ and $0.49 \mathrm{~km}$.

The estimated depths are quite close to those reported by [9] and by [24] $(0.325-0.600 \mathrm{~km})$. Similar estimated depth values were also obtained using a combination of geomorphological data, Lansat images and resistivity sounding and, by [1] $(5 \mathrm{~km})$ using a gravity anomaly grid in some parts of the Chad basin (Termit and Bornu basin).

\section{Conclusions}

We applied gravity polynomial fitting and spectral analysis to observed residual anomalies from the northern Logone Birni sedimentary basin of the far north region of Cameroon, to estimate the structure of the basin as well the depth of residual anomalies. The residual anomaly maps were obtained by fitting the Bouguer anomalies using polynomial surfaces of first, second and third orders 


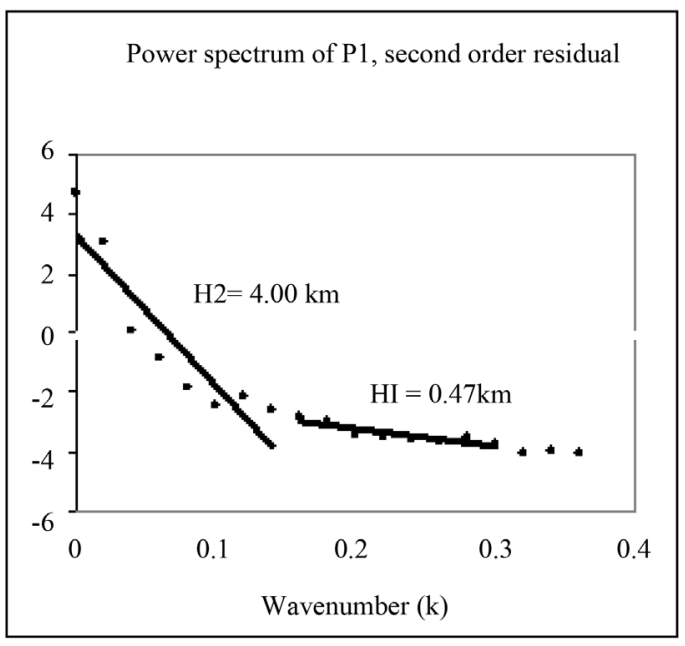

(a)



(b)

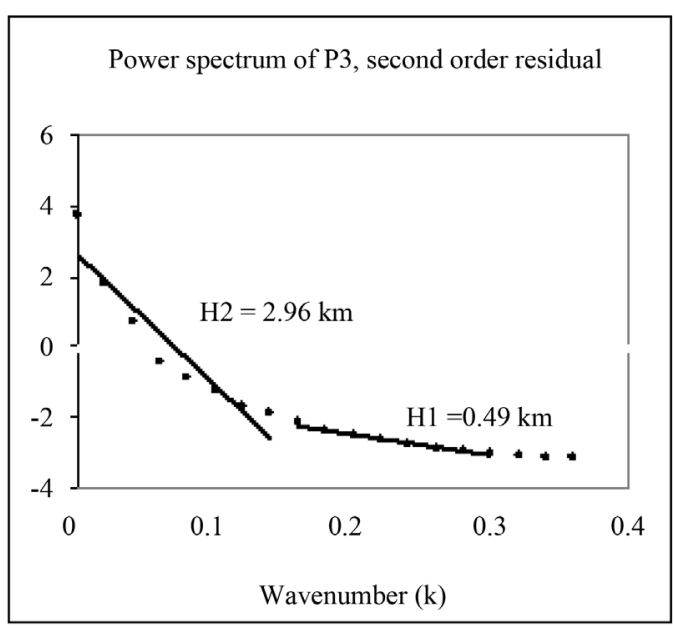

(c)

Figure 5. Power spectrum of profiles P1, P2 and P3 associated to the second degree trend gravity map. 


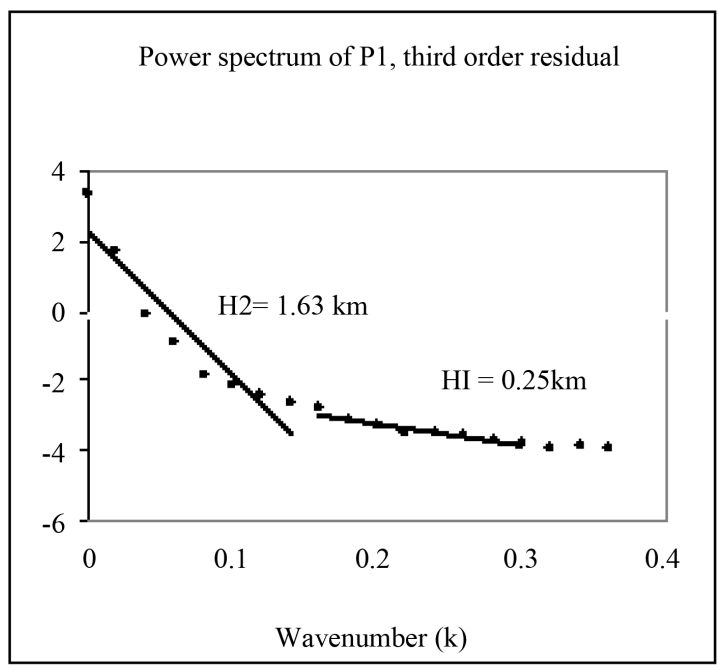

(a)

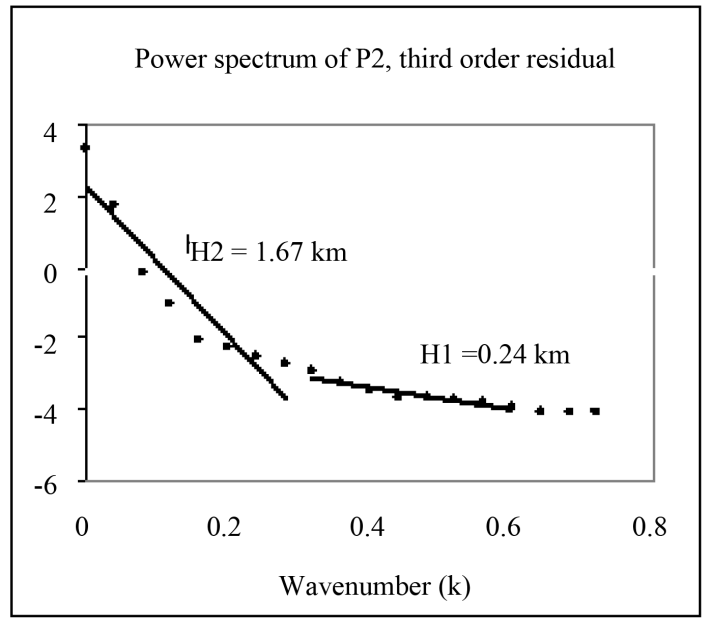

(b)



(c)

Figure 6. Power spectrum of profiles P1, P2 and P3 associated to the third degree trend gravity map. 
and 3 profiles were extracted to estimate the residual anomaly depths. The shape of the residual anomalies were found to be almost elliptical and trend N-S, NW-SE, NE-SW and are accompanied by a steep dipping gradient. Interpretations of the results show that the structural style of the Logone Birni Basin is mainly NE-SW.

Three distinct residual anomalies were identified in the basin. Over the Goulfey, the deepest anomaly is located at a depth of about 4.55, 4.00 and $1.63 \mathrm{~km}$, and the shallowest anomaly at $0.81,0.47,0.25 \mathrm{~km}$. Over the Tom Merifine, the deepest anomaly is located at a depth of about $2.10,2.09$ and $1.67 \mathrm{~km}$, and the shallowest anomaly at $0.34,0.34,0.24 \mathrm{~km}$. Over the Tourba, the deepest anomaly is at a depth of about $3.26,2.96$ and $3.84 \mathrm{~km}$, and the shallowest anomaly at 0.73 , $0.49,0.49 \mathrm{~km}$. The average residual depth along the basin varies between 0.24 $\mathrm{km}$ and $4.55 \mathrm{~km}$ with the minimum at Tom Merifine and the maximum at Goulfey.

\section{References}

[1] Fairhead, J.D. and Okereke, C.S. (1988) Depths to Major Density Contrast beneath the West-African Rift System in Nigeria and Cameroon and Its Tectonic Interpretation. Tectonophysics, 143, 141-159. https://doi.org/10.1016/0040-1951(87)90084-9

[2] Genik, G.J. (1993) Petroleum Geology of Cretaceous-Tertairy Rift Basins in Niger, Chad and the Central African Republic. Bulletin of American Association of Petroleum Geologists, 77, 1405-1434.

[3] Manga, C.S., Loule, J.P. and Koum, J.J. (2001) Tectonostratigraphic Evolution and Prospectivity of the Logone Birni Basin, North Cameroon-Central Africa. American Association of Petroleum Geologists Bulletin, 85, 1-6.

[4] Poudjom-Djomani, Y.H., Boukeke, D.-B., Legeley-Padovani, A., Nnange, J.M., Ateba-Bekoa, Albouy, Y. and Fairhead, J.D. (1996) Levés gravimétriques de reconnaissance-Cameroun. Orstom, Paris, $30 \mathrm{p}$.

[5] Nguimbous-Kouoh, J.J. (2010) Structure gravimétrique du basin sédimentaire de Goulfey-Tourba Tchad-Cameroun. Thèse de Doctorat/PhD de l'Université de Yaoundé I, Yaoundé, 100 p.

[6] Burke, K.C. (1976) The Chad Basin: An Intra-Continental Basin. Tectonophysics, 36, 192-206. https://doi.org/10.1016/0040-1951(76)90016-0

[7] Loule, J.P. and Pospisil, L. (2013) Geophysical Evidence of Cretaceous Volcanics in Logone Birni Basin (Northern Cameroon), Central Africa, and Consequences for the West and Central African Rift System. Tectonophysics, 583, 88-100. https://doi.org/10.1016/j.tecto.2012.10.021

[8] Burke, K.C. and Dewey, J.F. (1974) Two Plates in Africa during the Cretaceous. Nature, 249, 313-136. https://doi.org/10.1038/249313a0

[9] Isiorho, S.A., Taylor-Wehn, K.S. and Corey, T.W. (1991) Locating Groundwater in Chad Basin Using Remote Sensing Technique and Geophysical Method (Abstract). EOS (Transactions of the American Geophysical Union), 72, 220-221.

[10] Schneider, J.L. (1968) Carte hydrologique du Tchad au 1/500000. Rapport de synthèse. Rapp. B.R.G.M.

[11] Braide, S.P. (1990) Petroleum Geology of Southern Bida Basin Nigeria. American Association of Petroleum Geologists, 74, 617.

[12] Schuster, M., Duringer, P. Ghienne, J.F. Vignaud, P. Mackaye, H.T. Beauvilain, A. 
and Brunet, M. (2003) Discovery of Coastal Conglomerates around the Hadjer el Khamis Inselbergs (Western Chad, Central Africa): A New Evidence for Lake Mega-Chad Episodes. Earth Surface Processes and Landforms, 28, 1059-1069. https://doi.org/10.1002/esp.502

[13] Louis, P. (1970) Contribution de la géophysique à la connaissance géologique du bassin du lac Tchad. Mém. Orstom, Paris, 311 p.

[14] Mathieu, P. (1976) Évolution géologique récente du bassin du Tchad. Orstom, Paris, $12 \mathrm{p}$.

[15] Cratchley, C.R., Louis, P. and Ajakaiye, D.E. (1984) Geophysical and Geological Evidence for the Benue Chad Basin Cretaceous Rift Valley System and Its Tectonic Implications. Journal of Africa Earth Sciences, 2, 141-150. https://doi.org/10.1016/S0731-7247(84)80008-7

[16] Drake, N. and Bristow, C. (2006) Shorelines in the Sahara: Geomorphological Evidence for an Enhanced Monsoon from Palaeolake Megachad. The Holocene, 16, 901-911. https://doi.org/10.1191/0959683606hol981rr

[17] Murthy, I.V.R. and Krisshnamacharyulu, S.K.G. (1990) A Fortran 77 Programme to Fit a Polynomial of Any Order to Potential Field Anomalies. Journal of Association of Exploration Geophysicists, 11, 99-105.

[18] Gupta, V.K. (1983) A Least Squares Approach to Depth Determination from Gravity Data. Geophysics, 48, 357-360. https://doi.org/10.1190/1.1441473

[19] Gobashy, M.M. (2000) Basin Evaluation from Gravity Measurements using Simplex Algorithm with Application from Sirt Basin, Libya. Bulletin of Faculty of Science, Zagazig University, 22, 62-80.

[20] Spector and Grant (1970) Statistical Models for Interpreting Aeromagnetic Data. Geophysics, 35, 293-302. https://doi.org/10.1190/1.1440092

[21] Regan, R.D. and Hinze, W.J. (1976) The Effect of Finite Data Length in the Spectral Analysis of Ideal Gravity Anomalies. Geophysics, 41, 44-55.

https://doi.org/10.1190/1.1440606

[22] Pal, P.C., Khurana, K.K. and Unnikrishnan, P. (1979) Two Examples of Spectral Approach to Source Depth Estimation in Gravity and Magnetics. Paleogeoph, 117, 78-79.

[23] Avbovbo, A.A., Ayoola, E.O. and Osahon, G.A. (1986) Depositional and Structural Styles in Chad Basin of Northeast Nigeria. Bulletin of American Association of Petroleum Geologists, 70, 1787-1798.

[24] Schuster, M., Roquin, C., Duringer, P., Brunet, M., Caugy, M., Fontugne, M., Macaye, H.T., Vignaud, P. and Ghienne, J.F. (2005) Holocene Lake Mega-Chad Palaeoshorelines from Space. Quaternary Science Reviews, 24, 1821-1827. https://doi.org/10.1016/j.quascirev.2005.02.001

[25] Schull, T.J. (1988) Rift Basins of Interior Sudan: Petroleum Exploration and Discovery. Bulletin of American Association of Petroleum Geologists, 72, 1128-1142.

[26] Mohamed, A.Y., Wildlife, J.E., Ashcroft, W.A. and Whiteman, A.J. (2000) Burial and Maturation History of the Heglig Field Area, Muglad Basin, Sudan. Journal of Petroleum Geology, 23, 107-128. https://doi.org/10.1111/j.1747-5457.2000.tb00486.x 